\title{
Impact of Teaching Strategies on Medical Student Academic Performance
}

\author{
María Esther Urrutia-Aguilar ${ }^{1}$, Ruth Selene Fuentes-García ${ }^{2}$, Héctor García Vélez ${ }^{3}$, Edward Beck ${ }^{4}$, \\ Mónica Aburto Arciniega ${ }^{1} \&$ Rosalinda Guevara-Guzmán ${ }^{1}$ \\ ${ }^{1}$ Facultad de Medicina, Universidad Nacional Autónoma de México, Ciudad de México, México \\ ${ }^{2}$ Facultad de Ciencias, Universidad Nacional Autónoma de México, Ciudad de México, México \\ ${ }^{3}$ Facultad de Matemáticas, Universidad Autónoma de Guerrero, México \\ ${ }^{4}$ University of Illinois, College of Medicine, Chicago, IL, USA \\ Correspondence: Urrutia Aguilar María Esther, Facultad de Medicina, Universidad Nacional Autónoma de \\ 04510, México. Tel: 52-(55)-5553-7004. E-mail: mariau@unam.mx
}

Received: November 9, 2017 Accepted: December 6, 2017 Online Published: December 18, 2017

doi:10.5539/gjhs.v10n2p19 URL: https://doi.org/10.5539/gjhs.v10n2p19

\begin{abstract}
It is well known that teaching strategies used by educators in formal classroom are related to their beliefs, implied theories and practical thinking - strategies we refer to as pedagogical referents. The aim of this study was to determine whether there was a correlation between teaching strategies and medical student academic performance. A questionnaire developed to identify these strategies was given to course lecturers who taught a subject with a high student failure rate during the first two years of the career. The results show that there was a correlation between the teaching methods and the students' academic performance in core subjects.
\end{abstract}

Keywords: teaching strategies, academic development, medical students, learning

\section{Introduction}

In medical education, there is a consistent correlation between the strength of knowledge base acquired during pre-clinical years and the ability to its transition into clinical skills (Hojat, Gonnella, Erdmann, \& Veloski, 1997). Curricula in most Mexican universities, particularly at Universidad Nacional Autónoma de México (UNAM), are divided into yearly courses. In the School of Medicine, during the first two years, students attend classrooms, laboratories, and community health centers; then, in the following three years, they go to hospitals and ambulatory care centers. For this reason, a solid academic background in basic, clinical, and sociomedical sciences in the first two years is essential to develop clinical competences.

The mixed educational model for the Medical Surgeon Curriculum applied at UNAM is structured by core subjects, while focusing on the development of abilities (competencies). As a result, teaching strategies and pedagogical practices that educators use play a significant impact on students' academic performance, and consequently, the number of students successfully completing their medical training. Since the implementation of the current curriculum, there has been a high failing rate among students, particularly in the biomedical core sciences: Anatomy, Human Embryology, Biochemistry and Molecular Biology, Cell Biology and Medical Histology, Pharmacology, Physiology, Immunology and Microbiology and Parasitology (Muñoz-Comonfort, Leenen, \& Fortoul, 2014). At a global level, medical colleges and health professional academic institutions are identifying weaknesses in their curricula and collaborating on instructional and institutional innovations to develop a new generation of health professionals (Bhutta et al., 2010).

One of the main factors in the teaching-learning process are educators, and for centuries, they have been responsible for training and preparing the new generations of the medical workforce. Despite having the best curriculum, infrastructure, and teaching methods, any academic institution depends mostly on the quality and performance of educators. As a result, course lecturers and professors become one of the most significant variables in medical education. Not only do they provide a knowledge base, but also act as academic counselors, facilitators of learning, creators of educational resources, and a role model of ethical and professional behavior, among other activities and functions (Das, Sabban, \& Bener, 1996; Howard, Conway, \& Maxwell, 1985; Kremer, 1990; Marsh, 1984; Urrutia et al., 2014; Wilson, 1986). 
In a previous study from the Faculty of Medicine at UNAM, educator performance was assessed through student feedback and self-assessment. The results showed that the teaching strategies consistently received the lowest score (Urrutia et al., 2008, 2014). Teaching strategies are defined as the procedures educators use in a flexible, adaptive, self-regulated, and reflexive way to promote the achievement of meaningful learning among students, and they are often based on their own belief of how students learn best (Díaz-Barriga, 2003). Strand (2015) argued that one of the most critical factors for improving students' learning was to illuminate beliefs among teachers about learning, not to prove them wrong or right (Hattie, 2009; Timperley, Wilson, Barrar, \& Fung, 2007). However, the perspectives and experiences of medical instructors may be less well appreciated than are the perspectives of teachers in other education sectors (Biggs \&Tang, 2007).

These teaching strategies may be categorized on a theoretical basis that allow the formation of pedagogical referents which, according to Martínez et al. (2001), may be classified into three groups: the first being traditional referents (TR), which as a distinctive feature, are focused on the educator, and are the prevailing expository methods of traditional teaching (Gimeno \& Pérez , 1992); the second group is education technology (ET), which places the educator as the organizer and designer in the planning of activities, and passively observes student achievement of learning objectives (Pérez, 1993); and within the third group are the alternate referents, (AR) which have as a distinctive feature of student group participation in their own process of learning. In the latter category are all the innovating ideas in medical education, whose referents include: critical, constructive, psychogenetic, problem-based learning, and tutorials among others (Morán, 1993; Pérez, 1993). Pedagogical referents are the didactic methods of instructors, which result of their beliefs, implied theories and practical thinking that they assume, integrate, and use as own to teach within a determined social context (Pansza, 1993; Urrutia et al., 2014).

The development of the theoretical categories puts forward the question of whether pedagogical referents have a significant influence on student performance. In order to assess this, we evaluated the number of exam pass/fail grades across several core courses and the teaching strategy associated with the instructor of each respective course.

\subsection{Objective}

To classify pedagogical referents implemented by medical educators when teaching and to correlate them with students' academic performance in courses with low pass rates during the first and second years of medical school at UNAM.

\section{Method}

This is a cross-sectional, observational and descriptive study. Inclusion criteria were teachers who had taught a 1st or 2nd year course, with a significant number of failure rates during the first and second years in the 2010 academic year, and those who voluntarily answered the questionnaire $(n=126)$. These courses included Cell Biology and Medical Histology, Anatomy, Human Embryology, Pharmacology, Physiology, Microbiology and Parasitology and Introduction to Surgery.

The Ethics and Research Committees of the Faculty of Medicine at UNAM approved the research protocol. The results were used carefully guarding their confidentiality.

At the end of the school year, in May 2012, the questionnaire on pedagogical referents was given to instructors. It included 42 items, with a 4-points Likert type scale (from "totally agree" to "totally disagree) grouped into 5 strategies:

Learning (7 items): inquiries about the teacher's beliefs on responsibilities of learning and teaching.

Planning (4 items): refer to the activities' organization regarding teaching.

Methodology (17 items): the one used by the teacher according to his/her personal belief on how to approach the academic program's contents; for example, taking into account the student's skills.

Assessment (5 items): explore the purpose it represents for the teacher (to comply with objectives and feedback, among others).

Teacher-Student relationship (9 items): inquire about the teacher's beliefs regarding the relationship he/she establishes with his/her students.

It includes content validity and a Cronbach's alpha of 0.77 , which suggests a global consistency as reported in the literature (Martínez et al., 2001). The personal and anonymity data were carefully protected according with the Ethics and Research Committee of the Faculty of Medicine at UNAM. 
The excluding data for this study were the cases in which teachers did not answer any of the items (null data), or those who answered the same for all items.

Once the questionnaires were collected, the frequencies and percentages of the answers (42) in regard to "agree" or "disagree" were obtained, and subsequently each teacher was classified according to the pedagogical referent to which they belonged: traditional (TR), educational technology (ET), and alternative (AL).

In order to determine student academic performance, the average percentage of correct answers from the $1^{\text {st }}$ and $2^{\text {nd }}$ years in each office exam of the particular subject during 2011-2012 was considered. The exams were multiple choice, with a difficulty level from 30 to 70 and positive discrimination of 70 and 90 , graded between a range from 0 to 10 points, and designed by a licensed and reliable academic body. They were administered to all students simultaneously.

In order to establish the relationship between teaching strategy variables (learning, planning, methodology, assessment and teacher-student relationship) and the student academic performance, we obtained the Pearson's correlation coefficient between student grades and scores, as well as additive scales that grouped items by pedagogical referents. The pedagogical referent instrument reliability was assessed, and a descriptive and inferential analysis was performed using the SPSS v. 22.0 program.

\section{Results}

The grade averages obtained by 1,082 students in the different exams showed an academic achievement as observed in the histograms presented in Figure 1. The results of the analysis demonstrate a heterogeneity in student academic achievement: the poorest results correspond to Cellular biology during the first year (Figure 1a) and to Physiology at the second year (Figure 1b). A platykurtic-type distribution was observed in two areas of the second year (Pharmacology and Surgery), which shows low concentration on data around the media, and a higher concentration at the end.
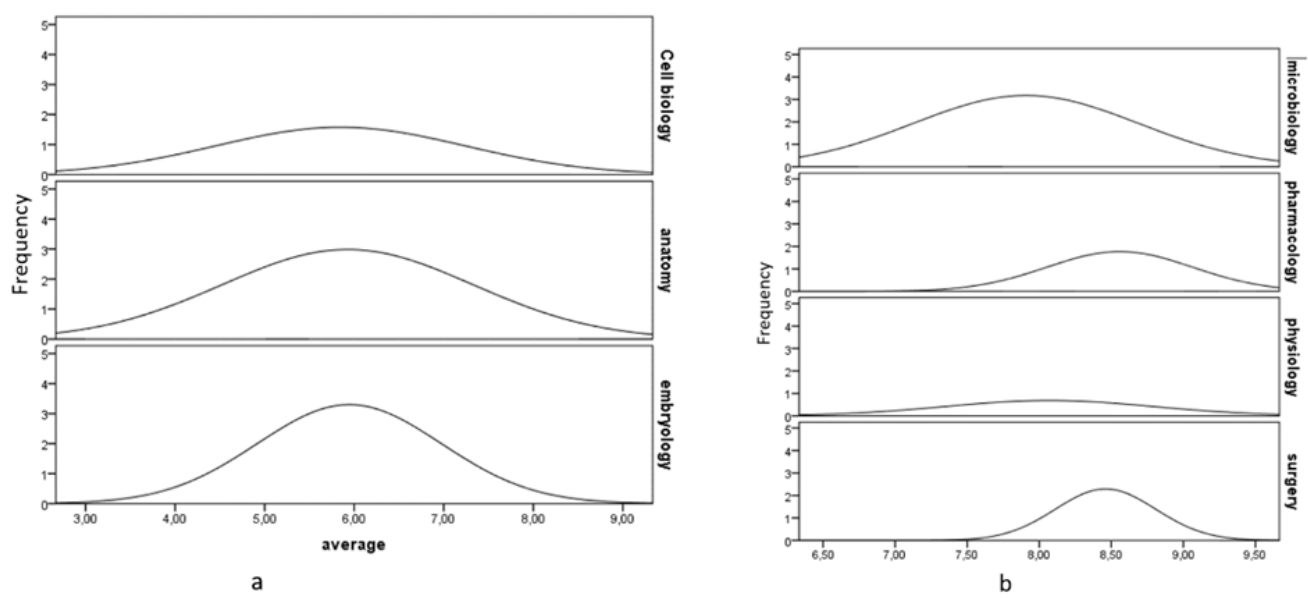

Figure 1. Smoothed histogram of the average obtained by the students on the first year's subjects (a), and on the second year's subjects (b)

Data correspond to 126 lecturers who had answered the full questionnaire (Table 1), 45\% of them were women and $55 \%$ men. Likewise, the average of their students was considered. 
Table 1. Number of lecturers by course who answered the full questionnaire

\begin{tabular}{ll}
\hline Course & Number of teachers \\
\hline Cell Biology and Medical Histology & 15 \\
Anatomy & 26 \\
Human Embryology & 19 \\
Pharmacology & 10 \\
Physiology & 16 \\
Microbiology and Parasitology & 26 \\
Introduction to Surgery & 14 \\
\hline
\end{tabular}

Table 2 shows the percentages according to what was reported by lecturers in regard to the pedagogical referent type, in agreement to their teaching strategies.

Table 2. Percentage of lecturers according to their strategy for each pedagogical referent.

\begin{tabular}{llll}
\hline \multirow{2}{*}{ Strategy } & \multicolumn{2}{l}{ PEDAGOGICAL REFERENTS } & \\
\cline { 2 - 4 } & Traditional \% & Educational Technology \% & Alternative \% \\
\hline Learning & $\mathbf{9 8}$ & 94 & 81 \\
Methodology & $\mathbf{9 5}$ & 78 & 62 \\
Planning & 83 & $\mathbf{9 6}$ & 15 \\
Assessment & 86 & $\mathbf{9 4}$ & 44 \\
Teacher-student relationship & $\mathbf{9 8}$ & & 91 \\
Average & 92 & 90 & 59
\end{tabular}

Note. The percentage in each referent is according to the percentage of agreeing answers in each strategy, taking into consideration that a teacher may agree with the three types of referents but that only one of them prevails.

Table 3 shows subjects, the items pedagogical referents that portrayed significant correlations between lecturers' answers with "agree" or "disagree" with the scores of students" choices.

Table 3. Correlations by subject based on pedagogical referents and the students' academic performance.

\begin{tabular}{|c|c|c|c|c|}
\hline $\begin{array}{l}\text { Teaching } \\
\text { school year }\end{array}$ & Subject & Question & $\begin{array}{l}\text { Pedagogical } \\
\text { Referent }\end{array}$ & Correlation \\
\hline \multirow[t]{5}{*}{ FIRST } & \multirow{2}{*}{$\begin{array}{l}\text { Cell Biology and } \\
\text { Medical Histology }\end{array}$} & $\begin{array}{l}\text { Planning: When the process of planning and learning } \\
\text { objective limitations is carried out, it promotes } \\
\text { students' participation }\end{array}$ & Alternative & 0.603 \\
\hline & & $\begin{array}{l}\text { Teacher-student relationship: It must be limited within } \\
\text { the classroom }\end{array}$ & Traditional & -0.604 \\
\hline & \multirow{3}{*}{ Anatomy } & $\begin{array}{l}\text { Method: The success of a class lies on the didactic } \\
\text { materials used }\end{array}$ & $\begin{array}{l}\text { Educational } \\
\text { Technology }\end{array}$ & 0.453 \\
\hline & & $\begin{array}{l}\text { Method: When seeking a theme, the relationship } \\
\text { among disciplines must be sought as well }\end{array}$ & Alternative & 0.449 \\
\hline & & Method: When studying theoretical concepts, I look & Alternative & 0.449 \\
\hline
\end{tabular}


for their connection to reality and their application

$\begin{array}{lllll}\text { Human } & \text { Assessment: I use evaluations to assess student } & \\ \text { Embryology } & \text { achievement and understanding of behavioral } & \text { Educational } & \\ & \text { objectives established in the program } & & \text { Technology } & -0.500\end{array}$

\begin{tabular}{|c|c|c|c|c|}
\hline \multirow[t]{8}{*}{ SECOND } & $\begin{array}{l}\text { Microbiology and } \\
\text { Parasitology }\end{array}$ & $\begin{array}{l}\text { Teacher-student relationship: A teacher must } \\
\text { incentivize desire of knowledge throughout the course }\end{array}$ & Alternative & 0.508 \\
\hline & \multirow{4}{*}{ Pharmacology } & $\begin{array}{l}\text { Method: There are subjects, which by nature require } \\
\text { to be mainly approached theoretically }\end{array}$ & Traditional & -0.703 \\
\hline & & $\begin{array}{l}\text { Method: I principally only teach theory without } \\
\text { applications }\end{array}$ & Traditional & -0.763 \\
\hline & & $\begin{array}{l}\text { Assessment: I use assessment only to give a final } \\
\text { grade to students }\end{array}$ & Traditional & -0.870 \\
\hline & & $\begin{array}{l}\text { Teacher-student relationship: The main function of an } \\
\text { instructor is being a facilitator of student learning }\end{array}$ & Alternative & 0.545 \\
\hline & \multirow{2}{*}{ Physiology } & $\begin{array}{l}\text { Learning: Learning is a process through which each } \\
\text { student acquires new knowledge provided by an } \\
\text { instructor }\end{array}$ & Traditional & -0.837 \\
\hline & & $\begin{array}{l}\text { Teacher-student relationship: Teacher-student } \\
\text { relationship must be limited within the classroom }\end{array}$ & Traditional & -0.926 \\
\hline & $\begin{array}{l}\text { Introduction to } \\
\text { Surgery }\end{array}$ & $\begin{array}{l}\text { Planning: In depth knowledge of the subject being } \\
\text { taught by the instructor (me) exempts me from } \\
\text { designing a course's objectives }\end{array}$ & Traditional & -0.792 \\
\hline
\end{tabular}

The analysis of the self-reported questionnaires demonstrate that alternative referents had the highest positive correlation with passing scores, while traditional referents had a negative correlation. As such, instructors with more alternative referents incorporated into teaching and less traditional referents correspond to the better student academic performance.

Furthermore, the analysis shows that the correlation with each item depends on the subject. In subjects taught during the $1^{\text {st }}$ year of medical school, student exam scores were positively correlated with instructors who were in more agreement with alternative referents, particularly in method and planning strategies.

In regard to Cell Biology and Medical Histology, higher exam scores were correlated with instructors who "strongly agreed" or "agreed" in the process and identification of limitations of learning objectives, which promotes the participation of students, and "strongly disagreed" or "disagreed" with limiting teacher-student interactions to the classroom.

While there was a low observed correlation between scores and referents for Human Anatomy, some consistencies were observed in questions answered and instructors with the highest exam's scores. In particular, these instructors were in agreement that success in the classroom lies on the didactic materials used, they often identified a relationship with other disciplines when teaching, frequently incorporated application of theory during lectures, and believed that the main role of an educator is facilitator of learning.

Interestingly, in Human Embryology students received higher grades when teachers used assessment as a main way to determine whether students had mastered the established objectives (correlation -0.500)

Biochemistry and Immunology were not considered in the results as they did not meet the inclusion criteria.

In the subjects being taught in the 2nd year of the academic curriculum, students had improved academic 
performance when the instructor "strongly disagreed" or "disagreed" with the traditional referents in regard to method strategies and teacher-student relationship.

In Pharmacology, we found that when instructors "strongly disagreed" or "disagreed" with presenting material in a theoretical way without providing application and final grades being the only basis of assessment, students most often had higher passing scores.

Physiology is the subject in which the most significant correlations were found ( -0.837 and 0.926$)$, showing that students succeeded the most when the instructor had indicated "strongly disagreed" or "disagreed" learning as the process through which the student acquires new knowledge solely through formal classroom teaching and the teacher-student interactions are limited to the classroom.

Overall, students had higher passing scores in Introduction to Surgery (subject belonging to the clinical area) with those instructors who "strongly disagreed" or "disagreed" with the statement that in-depth knowledge of the subject being taught by the instructor exempts him/her from designing course objectives.

The alpha de Cronbach in this instrument was 0.848815164 .

\section{Discussion}

The educational model of the academic curriculum of the Faculty of Medicine at UNAM is oriented to the development of medical competences, and therefore pedagogical practice that educators implement must focus on guiding students in their process of learning (Ornstein, 2011). However, instruction in the basic sciences is not easy, as they cover subjects in which knowledge is vastly extensive, starting from theories that must be analyzed and understood. As a result, many of these courses come with a steep learning curve, and a high failing rate. For this reason, it is imperative that alternative teaching strategies are developed to ensure that $1^{\text {st }}$ and $2^{\text {nd }}$ year students are succeeding academically (Campanario, 1999).

In general, it is denoted that teachers have traditional pedagogic referents, especially in regard to learning, methodology and teacher-student relationship; and assessment in Educational Technology given the influence of teachers on learning, their pedagogical practice must be adjusted to the needs of students. It is well known that teaching medical science with alternative strategies (Problem-Based Learning PBL) have had good results in the training of students (Brinkman, 2016).

The results of this study show the impact teaching strategies have on student academic performance. Subjects, such as Anatomy, may be considered more theoretical than practical to allow medical students acquire knowledge, of structures and relationships between human body's systems and organs. In this study, we identified educators that require adapting other alternative strategies, particularly oriented around methodology, in order to provide a solid foundation for other core subjects and clinical practice. Ganguly (2010) proposed a series of strategies, also innovating/alternative, that incorporate innovations in digital and internet technology, among others. However, it is important that a clear pedagogical design must be followed in order to provide targeted and structured teaching. Furthermore, as Pinsky et al. (1998) highlighted, involvement of learners, continuous innovation, and providing a positive atmosphere for learning are necessary for success in the teaching of pre-clinical sciences.

In previous studies, having a solid foundation of basic sciences was demonstrated to have a significant impact on further understanding of medical physiology (Guevara et al., 2015; Michael, 2006), it also provides evidence on how the role of active learning focusing on the student's perspective, can be used efficiently when teaching physiology. They demonstrated that among typical teaching strategies, active problem solving and collaborative learning yield consistently improved outcomes and positive students' feedback. Other studies in the past have identified negative correlations of this subject with the traditional referents, mainly traditional learning strategies and teacher-student interactions limited strictly to the classroom. As such, it is necessary that the educator must adopt new teaching strategies that facilitate the learning process of new generations of medical students.

The analysis for the Pharmacology course also demonstrated student performance was the highest when taught by lecturers that fell into the alternative type of referent. Based on the results from this study, an in-depth understanding of the pharmacological properties, actions, and interactions of chemical substances with the human body, as well as mastering clinical application of pharmacotherapies in the treatment and prevention of diseases is not possible through educational strategies with more of a traditional focus. Chavda et al. (2011) reported medical students strongly preferred interactive classes and problem-based learning through the presentation of medical cases and critical discussion of treatment options, instead of traditional lecture-based didactics. A recent cross-sectional study across fifteen European countries reported that medical students who had taken Pharmacology that focused on problem-based learning or mixed teaching methodologies developed 
better prescribing abilities, had greater knowledge of drugs and pharmacokinetics, and chose better therapeutics, which are essential competences of successful graduating medical students (Brinkman et al., 2016). It is very important to recognize the thorough knowledge of the fundamentals underpinning the rational use of drugs as a prerequisite for the adequate use of them in clinical settings (Urrutia et al., 2012).

However, this study suggests that lecturers apply what they had learned during their professional practice, but without being aware of their teaching needs and conveniences to teach according to any clear and effective teaching strategy. Hence, it is necessary to create a teaching training program specifically designed to strengthen the reflective ability on teaching practices that influences teachers to adopt new pedagogical referents (Urrutia et al., 2015). The challenge is to consider that, in educator training, the distance between declarative knowledge (theoretical knowledge) and practical knowledge (application knowledge) is still a big gap that will need to be narrowed by adding new teaching modalities based on praxis conceptions.

Moreover, the teaching strategies to be used in such courses must be structured according to the needs of educators so that they can acquire the adequate competences, skills, knowledge and attitudes to carry out quality teaching (Urrutia et al., 2015). In other words, we need teachers taught for educating future physicians more than for training them.

\section{Conclusions}

Since implementation of the new academic curriculum of the Faculty of Medicine at UNAM in 2010, there has been a high index of students' failure in the core basic science courses, which is considered the transitional years for students. Based on the evidence, this is likely, in large part, due to the teaching strategies used by instructors, which may not provide students with a clear understanding of the material or provide a forum that promotes and fosters critical thinking. In this study, we identified that pedagogical referents of the traditional type predominate during the transitional years $\left(1^{\text {st }}\right.$ and $2^{\text {nd }}$ year $)$; particularly in the learning teaching strategies, methodology and teacher-student interaction (Table 2). Over the six years since the implementation of the new curriculum, instructor assessments and training programs have been carried out to assess changes in the education paradigm that the competency-based curriculum demand. The continuous evaluation of these changes has made it evident that there is a significant opportunity for instructional improvement, particularly in the area of pedagogical measurement, as well as continued research into the best practices for educating current and future generations of physicians and medical scientists.

We consider that teachers mostly teach according to the way they were taught, and we assume that effective teachers engage learners and achieve some measure of students' success. Under these conditions, instruction processes consist in the application and analysis of the results of employing teaching strategies in order to produce and detect a reduction in students' achievement gaps. Although the relationship between differentiation of instruction (the role of teachers) and achievement gap (the role of students) is multidimensional, we propose that teaching strategies is the main link between instruction and achievement gaps.

We present some evidence that the expected transformations in the achievement gaps are the result of applying teaching strategies in the context of those dimensions of education characterized as referring to pragmatic, cognitive, humanistic and social issues. If such application of strategies is attained by superposition of some of these dimensions, the expected outcome is just training. If the application of teaching strategies corresponds to the integration of those dimensions, the outcome is education. Training would mean learning something concrete about a subject matter. However, if during the process of learning something, a deeper learning process is accomplished by enriching thinking, acting and becoming, then education is achieved.

\section{Acknowledgements}

The authors thank Josefina Bolado for the manuscript's English review.

\section{Competing Interests Statement}

The authors declare that there are no competing or potential conflicts of interest.

\section{References}

Bhutta, Z. A., Chen, L., Cohen, J., Crisp, N., Evans, T., \& Fineberg, H. (2010). Education of Health Professionals for the 21st Century: a global independent commission. Lancet, 375, 1137-8. https://doi.org/10.1016/S0140-6736(10)60450-3

Biggs, J., \& Tang, C. (2007). Teaching for quality learning at university: What the student does. Berkshire: Open University Press. Retrieved from https://www.amazon.com/Teaching-Learning-University-ResearchEducation/dp/0335242758 
Brinkman, D. J., Tichelaar, J., Schutte, T., Benemei, S., Böttiger, Y., Chamontin, B., ... Marandi, T. (2017). Essential competencies in prescribing: A first european cross - sectional study among 895 final - year medical students. Clinical Pharmacology \& Therapeutics, 101(2), 281-289. http://dx.doi.org/10.1002/cpt.521

Campanario, J. M., \& Moya, A. (1999). Cómo ense-ar ciencias?. Ense-anza de las Ciencias, 17(2), 179-192.

Chavda, N., Yadav, P., Karan, J., \& Kantharia, N. D. (2011). Second MBBS medical student's feedback on teaching methodology and evaluation methods in Pharmacology. National Journal of Physioly Pharmacy and Pharmacoly, 1(1), 23-31. https://doi.org/10.5455/njppp.2011.1.23-31

Das, M., Sabban, F., \& Bener, A. (1996). Student and faculty perceptions of the characteristics of an ideal teacher in a classroom setting. Medical Teacher, 18, 141-146. https://doi.org/10.3109/01421599609034149

Díaz-Barriga, F. (2003). Cognición situada y estrategias para el aprendizaje significativo. Revista Electrónica de Investigación Educativa, 5(2), 14-16.

Ganguly, P. K. (2010). Teaching and Learning of Anatomy in the 21st Century: Direction and the Strategies. The Open Medical Education Journal, 3, 5-10. Retrieved from https://benthamopen.com/contents/pdf/TOMEDEDUJ/TOMEDEDUJ-3-5.pdf

Gimeno, S., \& Pérez, G. (1992). Comprender y Transformar. Madrid: Morata. http://www.edmorata.es/libros/comprender-y-transformar-la-ensenanza

Guevara-Guzmán, R., \& Urrutia-Aguilar M. E. (2015). Curricular content level of complexity is a factor of depression and learning in medical students. Journal of Behavioral and Brain Science, 5, 274-279. https://doi.org/10.4236/jbbs.2015.57028

Hattie, J. A. C. (2009). Visible learning: A synthesis over 800 meta-analysis relating to achievement. London: Routledge. https://doi.org/10.1080/00071005.2011.584660

Hojat, M., Gonnella J. S., Erdmann, J. B., \& Veloski, J. J. (1997). The Fate of Medical Students with Different Levels of Knowledge: Are the Basic Medical Sciences Relevant to Physician Competence?. Advances in Health Sciences Education, 1, 179-196.

Howard, G., Conway, C., \& Maxwell, S. (1985). Construct validity of measures of college teaching effectiveness. J of Educ Psychol, 77(2), 187-196. https://doi.org/10.1037/0022-0663.77.2.187

Kremer, F. (1990). Construct validity of multiple measures in teaching, research, and service and reliability of peer ratings. Journal of Education Psychology, 82, 213-218. https://doi.org/10.1037/0022-0663.82.2.213

Marsh, H. (1984). Students' evaluations of university teaching: dimensionality, reliability, validity, potential biases and utility. Journal of Education Psychology, 76(5), 707-754. https://doi.org/10.1037/00220663.76.5.707

Martínez, G. A., Ferrés, G. A., \& Gutiérrez, D. S. (2001). Referentes pedagógicos y estrategias de ense-anza de los profesores de la Maestría en Ciencia Bioquímicas de la UNAM. Revista Anuies, 4(120), 54-59. Retrieved from http://publicaciones.anuies.mx/pdfs/revista/Revista120_S2A2ES.pdf

Michael, J. (2006). Where's the evidence that active learning works?. Advance in physiology education, 30(4), 159-167. https://doi.org/10.1152/advan.00053.2006

Morán, O. P. (1993). Fundamentación de la didáctica I (5th ed.). México: Gernika. Retrieved from https://www.elsotano.com/libro-fundamentacion-de-la-didactica-tomo-i-10033519

Mu-oz-Comonfort, A., Leenen, I., \& Fortoul-van der Goes, T. I. (2014). Correlación entre la evaluación diagnóstica y el rendimiento académico de los estudiantes de medicina. Investigación en educación médica, 3(10), 85-91. https://doi.org/10.1016/S2007-5057(14)72731-0

Ornstein, C. (2011). Curriculum foundation principles and issues. London: Mc Cutahan Publishing. Retrieved from https://www.amazon.es/Curriculum-Foundations-Principles-Educational-Leadership/dp/0132678101

Pansza, G. M. (1983). Sociedad-educación-didáctica.In: Fundamentos de la didáctica I. México: Gernika. https://es.scribd.com/document/313828643/MARGARITA-PANSZA-Sociedad-Educacion-y-Didactica-2

Pérez, J. E. (1993). "Problemática general de la didáctica". Fundamentación didáctica I (5th ed.). México: Gernika. Reteived from https://link.springer.com/article/10.1007/s10459-014-9546-0

Pinsky, E. L., Monson, D., \& Irby, M. D. (1998). How Excellent Teachers Are Made: Reflecting on Success to Improve Teaching. Advances in Health Sciences Education, 3, 207-215. 
https://doi.org/10.1023/A:1009749323352

Strand, P., Edgren, G., Borna, P., Lindgren, S., Wichmann-Hansen, G., \& Stalmeijer, R. E. (2015). Conceptions of how a learning or teaching curriculum, workplace culture and agency of individuals shape medical student learning and supervisory practices in the clinical workplace. Advances in Health Sciences Education, 20, 531-557. https://doi.org/10.1007/s10459-014-9546-0

Timperley, H., Wilson, A., Barrar, H., \& Fung, I. Y. Y. (2007). Teacher professional learning and development: Best evidence synthesis iteration. Wellington: Ministry of Education. http://www.oecd.org/edu/school/48727127.pdf

Urrutia- Aguilar, M.E., Barojas-Weber, J., Torres-Solis, J., Ponce-Rosas, E. \& Martínez- Gonzalez, A. (2008). Predictores de autoevaluación del desempe-o docente en ciencias de la salud. Educación en Ciencias de la Salud, 5(2), 21-30. Retrieved from http://www2.udec.cl/ofem/recs/anteriores/vol522008/artinv5208b.htm

Urrutia-Aguilar, M. E., Martínez-González, A., \& Rodríguez C. R. (2012). Measuring the Effectiveness of Pharmacology Teaching in Undergraduate Medical Students. Journal of Patient Safety, 8(1), 26-29. https://doi.org/10.1097/PTS.0b013e31823d0661

Urrutia-Aguilar, M.E., Guevara-Guzmán, R., \& Aburto-Arciniega, M. (2014). Efecto de un curso-taller de formación docente sobre los referentes pedagógicos de profesores de embriología. Revista de Investigación en Educación Médica, 3(12), 198-203. https://doi.org/10.1016/S2007-5057(14)70936-6

Urrutia-Aguilar, M.E., Sánchez-Mendiola, M., Guevara-Guzmán, R., \& Martínez-González, A. (2014). Comprehensive Assessment of Teaching Performance in Medical Education. Procedia-Social and Behavioral Journal, 141, 252-259. https://doi.org/10.1016/j.sbspro.2014.05.044

Wilson, R. (1986). Improving faculty teaching. Journal of Higher Education, 57, 196-211. https://doi.org/10.1080/00221546.1986.11778762

\section{Copyrights}

Copyright for this article is retained by the author(s), with first publication rights granted to the journal.

This is an open-access article distributed under the terms and conditions of the Creative Commons Attribution license (http://creativecommons.org/licenses/by/4.0/). 